\title{
Exile as Empowerment: Select Readings of the short stories of Mimi Lok
}

\author{
Barsha Dutta Kalita
}

Department of English Literature, The English and Foreign Languages University, India

Received: 16 Nov 2021; Received in revised form: 16 Dec 2021; Accepted: 26 Dec 2021; Available online: 31 Dec 2021 C2021 The Author(s). Published by Infogain Publication. This is an open access article under the CC BY license (https://creativecommons.org/licenses/by/4.0/).

\begin{abstract}
Reading Mimi Lok's select short stories through the lens of diaspora and exploring the possibilities of multiculturalism, this paper underscores the ever-transforming transnationalism that reinforces the concept of cultural hybridity of the diaspora. When looked into the two short stories by Mimi Lok, viz. "Last of Her Name" and "The Wrong Dave”, the ideas of home, sojourn, identity of the Chinese diaspora tend to take up new dimensions. 'Home' for the diaspora community is no longer just a token of longing but a station that liberates it from the burden of having to choose; that allows the hyphenated space not to be 'lacking' butto be all inheriting. Identity today means so much more than the binary us/them or the 'exile' and 'displaced'. Diaspora communities today possess the power to fashion their own cultural identity by blending the disparate elements that the world has to offer. A sojourner in the twentyfirst century stands rather as a transnational being with a sense of being an heir to all that he/she comes in contact with.This paper shall explore the journey of diaspora subjectivities from sojourn through settlement to transnationalism to highlight the process of assimilation, adaptation, cultural hybridity and mimicry respectively. It shall also look into the mother-land's sub-conscious desire of engaging in diaspora in search of empowerment.
\end{abstract}

Keywords-Diaspora, Transnationalism, Hybridity, Multiculturalism, Mimicry.

\section{INTRODUCTION}

Mimi Lok is an author, editor, and educator. She is the recipient of a Smithsonian Ingenuity Award and a Ylvisaker Award for Fiction. Mimi is also the founding director and executive editor of Voice of Witness, an award-winning human rights and oral history non-profit organisation that amplifies marginalized voices through a book series and a national education program. Born and raised in the UK, Mimi lived and worked in China as a visual artist, writer, and educator before moving to the US, where she is currently based. She is the winner of the 2020 PEN/Robert W. Bingham Prize for debut short story collection Last of Her Name, a California Book Award silver medal, and a Smithsonian Ingenuity Award. She is also a finalist for the 2020 National Magazine Award, Northern California Book Award, and CLMP Firecracker Award(About Mimi Lok, Squarespace)
Published in 2019, Last of Her Name is a short-story collection that portrays the interconnected lives of diasporic people and the histories they are born into. Set in a wide range of time periods and locales, including 80s UK suburbia, WWII Hong Kong and urban California, this short story collection allows readers to look into the lives of various characters belonging to different age groups, gender and class. The element of traveling not only in a spatial sense but also back and forth in a temporal sense is of much significance to the concept of diaspora at large.

Mimi Lok is able to offer her readers vantage points enabling them to understand the multiple layers of diaspora, specifically Chinese diaspora. Her works reveal that over the years, the feelings of exile of the diaspora have surprisingly entailed a sense of empowerment; the sojourners have settled and finally become transnational in nature.The multicultural possibilities that diaspora offers have reinforced the concept of cultural hybridity now more than ever. Although the hyphenated space veils an 
unavoidable sense of displacement, rootlessness, alienation, isolation and nostalgia, it also allows the diasporic community the power to fashion their own cultural identity by blending the disparate elements that the world has to offer. Assimilation, acculturalisation, adaptation as well as adeptation in the multicultural realm has indeed led to the creation of a cultural hybridity that empowers the hyphenated space, thereby, empowering its dwellers- the diaspora. In fact, this particular trait of empowerment that diaspora brings along has been a subconscious desire for people in their motherlands; for instance, the desire of the mountains of Gold has been therefor a long time.

Although the concepts of home, identity, gender, etc. in relation to diaspora studies have been explored extensively by taking into account the works of various writers, a few of them still remain unexplored. Mimi Lok's works have not received the due recognition, which is unfortunate in so far as they bring a fresh outlook to diaspora studies. This article intends to address this gap.

The first section of this article gives a brief over-view of Chinese diaspora and the concepts of cultural hybridity. Mimi Lok's outlook towards the state of diaspora is also highlighted. In the second section, this article will explore the process of transformation of the identity of the diaspora from one that isa mere sojourner to one that is settling down through the processes of assimilation and acculturalisation. This shall be explored with the help of Lok's short story "Last of Her Name". Lastly, the article will look into the diaspora subjectivities in the global era through Lok's short story "Wrong Dave".

\section{CHINESE DIASPORA: CERTAIN ISSUES}

Now, the term "Chinese diaspora" has been popularly used, especially in Euro-American countries, to refer to the Chinese living outside mainland China, Hongkong, Macau and Taiwan, all of which for convenience may be described as Chinese lands (Chee-Bang, 2013, "Introduction"). Although there is much debate around what constitutes diaspora, most scholars pay attention to the words of Clifford (1997:244)“experiences of displacement, of constructing homes away from home". Over the years, the study of Chinese in diaspora has developed significantly and its scope has widened tremendously. Speaking of population and distribution of Chinese diaspora, as per the research of Peter S. Li and Eva Xiaoling Li in "The Chinese overseas population" included in the Routledge Handbook of Chinese Diaspora, the majority of the Chinese diaspora are in Asia, especially South-east Asia, with about $75 \%$ andthe second largest concentration of the Chinese diaspora is in America which accounts for $19 \%(20)$. Indeed, there has been continuous migration from China to different parts of the world as well as remigration of the Chinese diaspora from one country to another, including remigrating back to China. Over the years, the Chinese diaspora has been impacted by various issues world-wide such as the ban on emigration by the Qing government and its eventual lift in 1893, the promulgation of Qing Nationality Law in 1909, the Chinese Exclusion Laws and their eventual repeal in 1943, the WWII, the Sino-Japanese War and so on and so forth. Nevertheless, this diaspora community has made a significant impact on economy, socio-political and cultural scenario globally.

In the realm of literature in particular, the Chinese diaspora's literary contributions are of great significance. The early records of literature by Chinese diaspora depicted longing for their homelands. Matters became complicated when these writers found themselves in a tugof-war between Chinese policies on migrants and their respective host-country's policies on immigrants. Concepts of nationalism, citizenship, ethnicity and above all, identity demanded negotiation on their part. Following China's May Fourth Movement, literary creation in Chinese vernacular by Chinese diaspora also saw a rise. In the recent decades, the issues and themes addressed by these writers are very diverse in nature and wide in scope for the advent of the era of globalisation and transnationalism. The growing research on the works of Chinese diaspora writers have highlighted the remarkable blend of memory and imagination in such works. In fact, books, both fiction and non-fiction, by Chinese diaspora writers have an upper-hand in the global popular literature of today.

\subsection{Hybridity and culture}

While discussing the concepts of culture and hybridity, Homi Bhabha's The Location of Culture(1994) is of prime importance. According to Bhabha, culture is something which is fluid. A notion of pure uncontaminated culture is a myth. Bhabha views culture not in its unchangeable essence, but one characterised by change, flux and transformation and most importantly by interconnectedness, which Bhabha terms "hybridity". His notion of culture as changeable and dynamic, characterised by hybridity of various elements is fundamentally inimical to the idea of nationalism and to the socio-political construct of a nation-state. Now, if one rejects the notion of cultural "essences" and thinks through the lens of cultural hybridity, then the kind of social organisation that one could turn to other than the nation state is indicated by Salman Rushdie in his Imaginary Homelands. Here, Rushdie urges us to look at ourselves as not grounded by any particular national culture, but as displaced beings who 
are living the life of an exile. But by being in this exile, one could become an heir to all cultures of the world and he/she could fashion their own cultural identity by creating a blend of elements that they prefer. Thus, the cultural identity then becomes a dynamic process of transformation and gives the diaspora far more agency to shape itself than is offered by the box of national identity.

In fact, globalisation and transnationalism have had drastic impacts on Chinese diaspora writers and their works. Exile could be now seen as a form of empowerment.Mimi Lok's life can in fact be seen as a perfect instance of the result of the empowering transnationalism. Her parents migrated to Europe from Hongkong and she was born in Epping, a small town outside of London, Europe. The tales of China that she heard from her mother left an indelible impact upon her. She visited Hongkong, lived and worked there for quite some time. Now, she has remigrated to the U.S. and is currently based there. Her identity is definitely a challenging one to trace; the doubly hyphenated space actually brings in further complications. In a session ofJLF Houston 2020, a virtual literary fest, Mimi Lok could be observed speaking of such complicacies that she is faced with every day:

I didn't spend anytime growing up in my parent's home-country China. So, [...] I don't think I have a real sort of a sense of a proper place growing up because I was growing up with dual cultures and often, you know, I think the question of loyalty came up, and so that was always confusing for me. Whenever the Olympics came on, I wasn't really ready to root on, U.K. yay! or China yay! or some other tiny country that's sort of surprising everybody and I sometimes found myself rooting for the third option [...] It's feeling as if you don't fully fully belong in one place or culture. (Diaspora and Displacement, YouTube)

Lok's words reveal that even though she is a second generation of diaspora, the problematics of diaspora are inescapable. Trajectories of dual cultures often put her to loyalty tests. Her feelings of not "belong(ing) to one place or culture" thus highlight her innate sense of displacement, alienation, isolation, rootlessness, fragmentation. However, it is quite fascinating that she mentions that often in the midst of having to prove her loyalty to either one of the two cultures that she grew up in association with, she prefers 'the third option'. Now, 'the third option' is one that is liberating yet all-encompassing. It indeed acts as a space attached with a sense of protection which lets her be loyal to both the cultures at the same time. This space could in fact be viewed as the hyphenated space; one that is witnessed to be a melting pot of all that makes one feel rootless, but in recent times has proven to be a ground of security and budding possibilities. Diaspora writers of modern day no longer fear the hyphenated space for they have learned that every dark cloud has a silver lining; the multi-cultural possibilities, the transnational identity and a cultural hybridity prove to be liberating for the diaspora.

In the same session, Lok also says that diaspora:

does put you on the margins or sort of like an inbetween sort of place but it's also a sort of a superpower as well. You get to observe things from different vantage points and then also looking for connections.(Diaspora and Displacement, YouTube)

Here, it is visible that diaspora writers of today truly experience the 'in-between' place as one that provides different taxonomies of power- political, socio-economic and cultural. Lok's short story collection, Last of Her Name is an excellent example that highlights the various concepts and forces of diaspora problematics as well as present-day view of the diasporic exile as empowerment.

\section{III. "LAST OF HER NAME"}

In the first short story of Lok's collection, the eponymous "Last of her Name", has strong undercurrents of diasporic consciousness. The narrative runs back and forth in time as well as space and carries small but certain tokens of memories that form the backbone of this tale. Very significantly, it also showcases processes of migration, eventual settlement, assimilation and acculturation.

The story mostly centres around Jun-Jun and her daughter Karen and their beautiful bond. The narrative runs back and forth among three time-scales and two placesEngland, 1983; this time frame portrays the present life of the family in England, again England,1970; this depicts the moments right after Jun-Jun's migration to England, and also Hongkong, 1941; this takes the readers back to JunJun's life in Hongkong on the eve of Sino-Japanese war. Here, these time frames shall be dealt with separately to understand the various concerns of Chinese diaspora.

\subsection{England, 1983}

The short story opens to this time frame in England and the readers encounter a mishap by a twelve-year-old Karen. Her attempt of recreating a scene from 'The Return of the Condor Heroes' and the eventual accident draw the reader's attention to the fact that this story is of mixed cultures. 'The Return of the Condor Heroes' is a Hongkong television series adapted from Louis Cha's novel of the same title. Thus, although the story set in England, it highlights strains of Hongkong life from the 
very beginning. Further it is told that this television series is Karen's favourite 'mou hap TV show' and that her father gets the "pirated recording of Hongkong shows delivered to their house each Saturday morning". Life of Chinese diaspora in the late twentieth century is encapsuled in the very first pages of Lok's short story. The first-generation diaspora- the father- would go to lengths of pirating TV shows in the process of reterritorialization. The second-generation diaspora- Karen- would naturally grow with a mindset far different from those children around her in England; for cultural tokens of both England and Hongkong surround her life. Although she was not born in Hongkong, the lifestyle offered to her by her parents has a huge impact on her life. While other children around her might spend their time day-dreaming of distant planets in different galaxies watching 'Benji, Zax and the Alien Prince', or fighting imaginary evils and saving sorcerers watching 'Into the Labyrinth', Karen as well as her sister spend their time trying to pull off martial arts- a strong cultural symbol of China. Lok describes:

Every weekend, the girls act out fight scenes from The Return of the Condor Heroes, running around the garden and swinging broom handles at each other, landing kicks and punches(Lok, 10)

The readers are formally introduced to Karen's mother, June Leung, when she calls the ambulance for her daughter was severely injured. The fact that her English is 'staccato' indicated that she is not a native speaker of English. Even after residing in England for twelve years, her English is broken:“Ambulance please! June Leung, 5 Clover Hill. Accident, bad fall. No, not me! My daughter.”(12)

However, both June and her husband Stanley have, in many ways, tried to cope and assimilate with the culture and lifestyle of England. June and Stanley's actual Chinese names are Jun-Jun and Ah Tin respectively, but they've taken up "English names" in order to adapt the English lifestyle. The narrator says:

Karen's parents reserve the use of their Chinese names for private debate over their girls, the business, the house, as well as moments of intimacy (13)

This adaptability of Jun-Jun and Ah Tin- of being able to put on different identities in different situations- is referred to by Karen as a "talent". However, her innocent mind also fears that her parents "are not actually who they say they are" and this might result in some "dreadful punishment" by the people around them who can recognise from their appearance that they are "chink", that is, of Chinese descent. This charade ofJun-Jun and Ah Tin of being "not actually who they say they are"(14) highlights the complexities of dual identities that people of diaspora experience- the price that they pay to assimilate. Here, it can also be pointed out that the effort on the part of the diaspora of trying to assimilate with the local culture of the host-country by incorporating traits of that culture into the lives is similar to that of Homi Bhabha's concept of mimicry. Although the diaspora tries to mimic the ways of the culture of the host-country, they are not seen as people of that culture; they "almost" belong to that culture.

Tan Chee-Bang, in the "Introduction" to the Routledge Handbook of the Chinese Diaspora, notes that "having settled down in foreign lands, Chinese emigrants tried to reterritorialize their familiarChinese ways of life, although this process was influenced by their need to adapt to the localconditions"(8). Jun-Jun's act of bringing along an embroidered picture of "two cranes perched on a treetop that symbolized matrimonial harmony"(21) with her from Hongkong to England, and Ah Tin's act of bringing pirated TV shows of The Return of the Condor Heroes can be highlighted as smalls steps of reterritorialization by the Chinese diaspora which, however, came at the cost of their steps of adaptation of and assimilation with the local conditions of the host-nation; such as their act of taking up English names, adjusting in a cul-de-sac, a kitchen "toobright", a blocked-Chi and an evil omen.

\subsection{England, 1970}

This time frame delineates the experience of Jun-Jun's experiences right after she migrates to England. The immediate expression that the readers gain from Jun-Jun's thought is: "I can't live here"(18); she found the Clover Hill "leafy, manicured, and quiet"(18). It is quite the contrast to her life in Hongkong where she was used to an engrossing life. Often, she would try to find comfort amidst little things around her that resembled her life back in Hongkong:

The noise of the street and the smell of grease from the chip shop downstairs had made it easier to pretend she was back in Kowloon City, with its maze of neon ladders and the reassurance of dense, close moving bodies. (22)

Moreover, the English lifestyle of shaping hedges or preferring cul-de-sac make her uneasy. Ill omens associated with Chinese culture like having a house on the top of the row drains good fortune away or Chi being blocked by a wall seem insignificant in England. Here, the readers learn about Jun-Jun and Ah Tin's marriage. The narrator depicts: "He'd left for England a few months after the wedding, following in the steps of countless men seeking better prospects overseas"(19)

This highlights that the Chinese men chose to migrate to Europe, U.S. and other North-American nations for the 
want of better prospects. The initial hardship of such men of Chinese diaspora are described by the narrator:

She(Jun-Jun) imagined his dingy bedsit, riddled with mould and cockroaches, and the floorboard under which he'd secrete money from his week's wags in a biscuit tin, saving toward their reunion fund. She imagined his cold, lonely nights in the restaurant basement, hunched over metal pails of potatoes as he scraped their skins off one by one practising English phrases ("Good evening, Sir, Madam" "Have you made a reservation?" "I would recommend the lobster") that would get him out of the basement and secure a front-ofhouse position. (20-21)

As noted by Tan Chee-Bang in his "Introduction" to the Routledge Handbook of the Chinese Diaspora, "In America and Europe,Chinese businesses were in the past confined to restaurants andlaundries"(7), Ah Tin indeed opens a restaurant in England and settles down by eventually bringing his wife along. Jun-Jun gives a hair-cut to the younger waiters of their restaurant and makes them "all look like Chinese Steve McQueens"(30) which further indicate that the immigration of Chinese to England continued and were helped through their struggle of settlement by earlier immigrants. This is an instance of chain migration. The "light,swift motion of her fingers in their hair" fills the young boys with "a strange longing-a combination of lust and homesickness"(31). Here, it can be highlighted that although the boys longed for their homes or wives even at the touch of Jun-Jun's fingers, "the warning steel against their necks and ears"(31) kept them in check as if reminding them the reasons of their immigration- better opportunities overseas- and promises to their wives.

Now, Early Chinese migrants were predominantly men, but women were also involved in migration, which was after all a family strategy. As Huping Ling points out in her work "Negotiating transnational migration: marriage and changing gender roles among the Chinese diaspora" in the Routledge Handbook of the Chinese Diaspora,often the wives were left behind by their emigrated husbands and such women lived lives of widows of living husbands. Ling highlights:

A widely spread and popular folk song among the overseas Chinese villages starts with the lyric "dangnian agong xia nanyang, jiali apo ku duanchang" or "A man left for Southeast Asia, his wife wept until she was broken hearted" (author's translation), depicting the plight of wives who were left behind by their emigrant husbands. The villages with substantial numbers of Chinese overseas were called "widow villages. Such folk song and sobriquets best describe the split family life a transmigrant and his family had to endure (232)

Somewomen did migrate, although more did so only since the first few decades of the twentiethcentury. Jun-Jun was one of those few women who did migrate to their husband's place in a new nation.

She was determined to struggle her way into settlement. Even when she thought of having a baby boy as her second child, she makes it very clear that namelines don't matter to her; she thinks: "What good is preservation, after all? Only survival matters." (32). This further shows the fact that assimilation indeed comes with a price-tag, one that the diaspora is now willing to incur for the sake of a better life.

\subsection{Hongkong, 1941}

This time frame opens to Jun-Jun's childhood in Hongkong and the backdrop is the second Sino-Japanese War. The readers learn that she probably 11 or 12 -yearold, just about the age of Karen in the story and is trained in martial arts by her Great Uncle Chutt. An unnamed and mysterious character, "the boy", is also introduced. JunJun was a strong and sensible person right from her childhood who managed everything on her own. However, patriarchy in the guise of her Great Uncle Chutt had declared that Jun-Jun should marry the boy. Although she felt "a knot in her chest and a tear forming in her left eye" (29), she told herself "Just accept it until you find some other way" (29). Eventually, Lok's short story leaves the readers at an open-end when they learn that she might lose the boy in a crowded street intentionally or by sheer fate; one could certainly doubt if this was Jun-Jun's "other way".

This time-frame runs parallel to their present- England, 1983, where Karen too is stalked and abused by a notorious boy from her school named Ricky Stokesanother instance of women being mere objects of amusement for a patriarchal society. She decides to build herself stronger so that she could fight him off and practices some push-ups and weightlifting. In this process she is helped by her mother who eventually plays a role in getting rid of Ricky Stokes. The readers are given no clue of how Jun-Jungot rid of Ricky Stokes, there was not a trace of him to be found. This resembles the way Jun-Jun got rid of "the boy" from Hongkong.

The two time frames with different places are indeed seen in a relation to each other in the narrative. Whenever the readers are given a glimpse of Karen in England in 1983 and she is found engaged in some kind of martial arts charade or working out, the readers are automatically taken 
to Jun-Jun's childhood in Hongkong, 1941. Such flashbacks feel as thoughthey resemble the memories of Jun-Jun that often run back and forth in time whenever she sees someone or something in relation to her life back in Hongkong. It is as though the memories never leave her side; they come and go just as abruptly as the narrative itself is witnessed running back and forth temporally and spatially. This experience of often having flashbacks is common to the diaspora; specifically, the first-generation diaspora for they've lived the moments that come to them as flashbacks. However, it is significant that unlike other tales of diaspora where flashbacks of home and past life often bring nostalgia and the diasporic consciousness is almost impossible to resist and even burdening at times, Lok's characters are different. Jun-Jun does have flashbacks very often, but she is witnessed to have coped with them. She is instead liberated in the in-between space; she thinks of her past and learns from them.This is evident when she helps Karen in her work out. She remembers her days of martial arts; recalls the lessons she learnt and occasionally throws out instructions:

how Karen is holding herself wrong, how she needs to bend her knees a little here to stop from hurting herself. She tells her to breathe from the abdomen, not the upper chest; to be mindful of posture and correct alignment, how this will the direction of her chi. (41)

Thus, it is quite evident that as the sojourners tend to settle and assimilate, their identity in the hyphenated space seems to be empowering than ever. They could get the best of both worlds if they choose to. In this era of globalisation, transnational and multi-cultural possibilities could make the diaspora so much more empowered rather than mere exiles.

\section{IV. "THE WRONG DAVE"}

This short story seems to be a case of mistaken identity which, however, is not really solved even till the end. The readers are left wondering if "Dave", the protagonist, is the actual Dave to whom Yi, a girl from Hongkong, is writing e-mails to. Lok in this short story presents her reader with subtle but sure problematics of diaspora. However, the concept of transnationalism facilitating empowerment to the diaspora is more dominant here.

The short story is set in the year 2002. Dave is an architect living in England but his origins can be traced back to Hongkong. The narrator doesn't provide the readers with details of his life back in China or whether he was entirely born and brought up in England. Descriptions about the protagonist's origin, home, identity are not the focus here; as if indicating that none of those matter in the modern era of globalisation. He could travel back to Hongkong to meet his family and friends as and when he wants and then come back to England where he enjoys his profession. He is the face of twenty-first century diaspora who love the "better prospects" that can be found in another nation and yet, liberally enough, feel connected to any culture at will.

The readers also meet $\mathrm{Yi}$, the girl from Hongkong whom Dave met 3 years ago at his cousin's marriage back in Hongkong. Dave receives e-mails from her, strangely enough, after three long years while she was the one who didn't choose to keep in touch with him when they last met. All the while, Dave doubted if she had e-mailed him mistakenly and that he was "the wrong Dave"; but he never knew it for sure. Yi is a camera operator for TVB who is busy in her life and at times, wishes to take a break from the humdrum of life by intaking alcohol and even attending marriages she is not invited to. The readers know from her e-mails that she has recently lost her grandmother Popo and that it has impacted her deeply. After the funeral rites of her grandmother are over, the readers learn that she is flying to the U.S. and starting life over.

Now, through her e-mails, it is also evident that she is one those people in the diaspora who chose to engage in it for the sheer excitement of exploring the world. After completing her high-school studies, she worked hard in a warehouse and in her uncle's store to save some money. Then she left for the U.S. Yi explains:

The day I left for the States, Popo said she was so proud of me. She didn't care that I was going to a crummy community college in a crummy beach town. To her, someone who never got the chance to go to school, I was flying to the Gold Mountain to get an Important American Education. (83)

Here, it can be observed that $\mathrm{Yi}$ chose to migrate to the U.S. for attaining some kind of amusement in her life, even if she was attending some substandard educational institute. But this did not matter for her grandmother; education offered by America was considered "important" and America was still the "Gold Mountain" for people of the older generation of China. "Gold Mountain" is a term historically used broadly by Chinese to refer to western regions of North America, including British Columbia, Canada.After gold was found in the Sierra Nevada in 1848, Chinese people from Toisan in Guangdong, began to travel to the West in search of gold and riches during the California Gold Rush. This concept is beautifully explained by Henry $\mathrm{Yu}$ in his work "Mountains of gold: Canada, North America, and the Cantonese Pacific" included in the Routledge Handbook of the Chinese Diaspora by Tan Chee-Beng. He says: 
It is a truism that before a migrant takes their first step away from home, a dream has to come in the opposite direction along the path to be taken. The aspirations that drew individual migrants out of rural villages in Guangdong were created out of the intelligence and information that Canada, North America, Cantonese Pacific was passed back along the familial networks built along the shipping and mail routes. News about the financial success of a relative, the kinds of work that might be found, the amount of savings that could be amassed over a year in specific jobs, the relative merits of various destinations around the Pacific - all of this and more passed through word of mouth and in letters around the Pacific. (111112)

Although the aspirations of Gold-Mountain were maleoriented initially, towards the later part of the twentieth century, women too knitted the same dreams. Yi was a perfect example of this. However, Yi had to come back to Hongkong to look after her ageing grandmother. Later, when her grandmother passes away, Yi doesn't choose to stay in Hongkong anymore. She takes off to the U.S. to do a little dance movie. She writes to Dave: "I have my passport, ticket, and $\$ \$ \$$ " (104). This reflects her innate desire to involve in the diaspora- to live in a hyphenated space which is empowering rather than a rootless cold space. Instead, growing up without parents right from childhood and eventually losing her grandmother, the only person whom she truly loved, Hongkong seemed rootless to her. In fact, for many people like her in the global age, a passport, a ticket and some U.S. dollars are all that it takes to start a different life right from scratch. It can be opined that now, the hyphenated space is a safe space for people like $\mathrm{Yi}$ who are ready to explore, assimilate and have a transnational existence.

\section{CONCLUSION}

Diaspora, thus, can be observed to offer more possibilities today than we ever imagined. In this global world where national boundaries are mere imaginary lines on the maps, experiences of diaspora are empowering rather than abandoning one in an exile. The hyphenated space is a melting pot of several disparate elements which are regularly being added and which are regularly transforming our cultural identities. An identity today has so much more to it, it is no longer a singular idea. Mimi Lok brilliant answer to the question on her identity explains the essence of this paper:

I don't know... when people call me an AsianAmerican writer, I think "fine", someone calls me a British-Chinese writer, "fine, that's totally fine"(Diaspora and Displacement, Youtube, 2020)

This idea of being "fine" with the blended identities, of inheriting all, is the crux of Diaspora in the twenty-first century. Lok's two short stories, viz. "Last of her Name"and "The Wrong Dave" are able to portray the various problematics of Chinese diaspora in two different time spans; one around the 1980s and the other around the 2000 s, respectively. The change in the century is also reflected through certain changes in the diaspora experiences. In "Last of her Name" the sojourners are seen to taking small but certain steps towards assimilation and eventual settlement, while in "The Wrong Dave", the diaspora identity already seems to have become transnational in nature. Both these aspects are very integral to the idea of diasporic consciousness.

With the concept of cultural hybridity at play, nobody is actually in a proper demarcated space; I believe the hyphens have an impact on either side. Further research could be done in this aspect to analyse the impacts of the diaspora on the motherland and the host-country in the modern times.

\section{ACKNOWLEDGEMENT}

This paper, "Exile as Empowerment: Select Readings of the Short Stories of Mimi Lok", began asan inspiration for my research along the lines of Diaspora problematics across different cultures. The various issues related to study of migration and diaspora were highlighted to me by Dr. Mridul Bordoloi, Professor, Department of English, Dibrugarh University. I thank him for guiding me and suggesting me the necessary changes needed in this paper. I am grateful for his cooperation and patience. I also wish to thank the International Journal of English Literature and Social Sciences (IJELS) for allowing me an opportunity and a platform to express my views and promote research.

\section{REFERENCES}

[1] Lok, Mimi. (2019).Last of Her Name, Kaya Press.

[2] Chee-Beng, Tan. (2013). "Introduction", Routledge Handbook on Chinese Diaspora, London and New York: Routledge.

[3] Li, Xiaoling. (2013). "The Chinese overseas population", Routledge Handbook on Chinese Diaspora,London and New York: Routledge.

[4] JLF. "Each of Us Writers: Diaspora and Displacement", YouTube, Accessed 1 Dec 2021.Retrieved from www.youtube.com $/$ watch? $\mathrm{v}=3 \mathrm{Z} 5 \mathrm{vbmyfPlg} \& \mathrm{t}=562 \mathrm{~s}$

[5] Ling, Huping. (2013). "Negotiating transnational migration: marriage and changing gender roles among the Chinese 
diaspora",Routledge Handbook on Chinese Diaspora,London and New York: Routledge.

[6] Yu, Henry. (2013). "Mountains of gold: Canada, North America, and the Cantonese Pacific", Routledge Handbook on Chinese Diaspora,London and New York: Routledge.

[7] Lahiri, Himadri. (2019). Diaspora Theory and Transnationalism,Allen Hibbard (Editor), Orient Blackswan Private Limited.

[8] “About Mimi Lok”, Squarespace. Accessed 10 Dec 2021. Retrieved from www.mimilok.com/about

[9] Clifford, James. (1997).Routes: Travel and Translation in the Late Twentieth Century, Cambridge, MA: Harvard University Press.

[10] Cohen, Robin. (2008). Global Diasporas: An Introduction, London and New York: Routledge. 